\title{
Alternative Dispute Resolution in Employment Dispute Completion Between Indonesian Companies With Foreign Workers
}

\author{
I Wayan Gde Wiryawan ${ }^{1,2, *}$ Dewi Bunga ${ }^{1}$
}

\author{
${ }^{1}$ Faculty of Law Universitas Mahasaraswati Denpasar, Denpasar, Indonesia \\ ${ }^{2}$ Departement of Law, Institut Hindu Dharma Negeri Denpasar, Denpasar, Indonesia \\ *Corresponding author. Email: gdewiryawan1976@gmail.com
}

\begin{abstract}
Globalization in various fields and the advancement of information technology have an impact in increasing the need for companies in Indonesia to employ foreign workers. Foreign workers are expected to provide technology transfer to local workers. The existence of foreign workers working in Indonesian companies is bound by work agreements. Each party must implement the rights and obligations as stipulated in the employment agreement. Even though the parties are obliged to submit to the work agreement, a labor dispute between the company and foreign workers is still possible. In this study, there will be two problems examined, namely can the labor dispute between Indonesian companies and foreign workers be resolved through alternative dispute resolution? and which law is used in dispute resolution through alternative dispute resolution? This research is normative juridical research. Legal material consists of primary material and secondary legal material. Materials are collected through document studies. The analysis is carried out qualitatively. Labor dispute resolution between Indonesian companies and foreign workers can be resolved through alternative dispute resolution. The dispute resolution through alternative dispute resolution uses the law chosen by the parties as stipulated in the work agreement
\end{abstract} Keywords: Disputes, foreign worker, companies, and alternative dispute resolution

\section{INTRODUCTION}

The issue of foreign workers has been the topic of much debate in Indonesian media. Ahead of the 2019 legislative and presidential elections political opponents of Indonesian President Joko Widodo are seemingly using this topic to gain popularity and to incite criticism on the government, or even to incite anxiety in society. ${ }^{i}$ The presence of foreign workers on the one hand is seen as a necessity, but on the other hand it is seen as an obstacle for local workers to get managerial positions in large companies.

The development of globalization is driving the movement of capital flows and investments to various parts of the world. There is also migration of population or movement of labors from one country to another countries. The labor movement takes place because investments made in other countries generally require direct supervision by the owner / investor. ${ }^{\text {ii }}$ Indonesia must be ready to face the rush of liberalization that involves the ability to prepare the quality of human resources as workers to be able to compete for local and international labor markets. ${ }^{\mathrm{iii}}$ The involvement of foreign workers is needed in increasing the development of companies in Indonesia.

Opportunities for the emergence of foreign workers in Indonesia began with the ratification through The Law of Republic of Indonesia Number 7 Year 1994 concerning the Ratification of the Agreement Establishing The World Trade Organization. In addition, the existence of the General Agreement on Trade in Services (GATS) also opens opportunities for foreign workers. Activities providing services in GATS are categorized in the following groups:

1. Services that are supplied from one country to another are officially called cross-border supply.

2. Consumers or a business entity that uses services in other countries, official consumption abroad.

3. Foreign companies that set up branches outside their countries are officially referred to as commercial presence.

4. Individuals who travel abroad to provide services, officially called the presence of natural persons. $^{\text {iv }}$

Normatively, the definition of foreign workers is regulated in Article 1 number 13 of Law Number 13 of 2003 concerning Manpower. The regulation states that foreign workers are foreign nationals holding a visa with the intention of working in the territory of Indonesia. Foreign workers are pretty much involved in various sectors in Indonesia. The Ministry of Manpower stated that the number of foreign workers working in Indonesia on 31 December 2018 with total amount of 95.335 people, in which 30.626 workers were professional foreign workers, 21.237 were managers, and 30.708 were consultants and directors. The number of foreign workers in 2018 had 
indeed increased compared to 2017 which only 85.974 . The increase occurred because investment of other countries in Indonesia has been increasing. The number of foreign workers who came to Indonesia were from China (32.000), Japan (13.897), Korea (9.686), India (6.895) and Malaysia (4.667). ${ }^{\vee}$

For all companies, hiring foreign workers is actually not a small burden. The cost to employ foreign workers can reach 3 to 4 times compared to local workers. Aside from the substantial salary, foreign workers still receive additional facilities such as vehicles and drivers, apartments, health services, and the cost of returning home. Especially for Eastern countries like Japan, Korea and China, they have a very closed system of belief circle. It is difficult for them to trust people from other nations. Therefore, not giving positions to local workers is not a technical matter of expertise, but a non-technical matter, namely trust. Japanese, Chinese and Korean people are generally not proficient in English, likewise Indonesian workers and management in the holding company. For this reason, strategic positions in the company are still held by foreigners. ${ }^{\mathrm{vi}}$

The legal relationship between foreign workers and companies in Indonesia is not always going well. Sometimes, there are various conflicts that can cause disputes in the employment relations. The disputes can be triggered by violations of work agreements such as inappropriate salaries, minimal health facilities, conflicts with colleagues and so on. Foreign workers are entitled to legal protection. One form of legal protection for foreign workers is the settlement of disputes between foreign workers and the company where they work. In this study, there are two legal issues that are examined namely whether labor disputes between Indonesian companies and foreign workers can be resolved through alternative dispute resolution and which law is used in dispute resolution through alternative dispute resolution. This legal question is important to study considering the parties (foreign workers and companies in Indonesia) are bound to two different jurisdictions.

\section{RESULT AND DISCUSSION}

\subsection{Labor dispute resolution between Indonesian companies and foreign workers through alternative dispute resolution}

The inflow of foreign workers into Indonesia cannot be avoided only by observing the interests of the free labor market (globalization and liberalization) and the national interest. In national development, capital / investment, technology and foreign experts are needed, because the domestic labor market is not yet fully able to provide experts / skills both in quantity and quality. ${ }^{\text {vii }}$ According to Ahmadi Miru, the basic philosophy of using foreign workers is as a series of efforts to increase investment, transfer of technology and transfer of skills to Indonesian workers, as well as expansion of employment

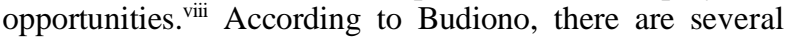
objectives for the placement of foreign workers in Indonesia, as follows :

1. Fulfilling the needs of skilled and professional workers in certain fields that cannot yet be filled by Indonesian workers.

2. Speeding up the process of national development by accelerating the process of technology or knowledge transfer, especially in the industrial field.

3. Providing expansion of employment opportunities for Indonesian workers.

4. Increasing foreign investment to support development capital in Indonesia. ${ }^{\text {ix }}$

The government as the holder of sovereignty is obliged to draw up legislation and regulations in the field of labor. The government is also obliged to guarantee the upholding of the regulations and conduct industrial relations. Basically, the industrial relations are the processes of maintaining communication, consultation, and discussion, and they are supported by the ability and commitment of all elements in the company. ${ }^{\mathrm{x}}$ On the basis of real needs in the field, the Government of Indonesia issued a number of policies to employ foreign workers, including:

1. Law Number 13 of 2003 concerning Manpower

2. Republic of Indonesia Labor and Transmigration Regulation Number 12 of 2013 concerning Procedures for the Use of Foreign Workers

3. Government Regulation of the Republic of Indonesia Number 97 of 2012 concerning Traffic Control Levies \& Extension of Hiring Foreign Workers

4. Presidential Regulation of the Republic of Indonesia Number 20 of 2018 concerning the Use of Foreign Workers

5. Decree of the Minister of Manpower and Transmigration Number 40 of 2012 concerning Certain Positions forbidden to Occupy Foreign Workers.

6. Regulation of the Minister of Manpower Number 10 of 2018 concerning Procedures for the Use of Foreign Workers, Regulation of the Minister of Law and Human Rights Number 16 of 2018 concerning Procedures for Granting Visas and Residence Permits for Foreign Workers.

The purpose of the regulation regarding foreign workers in terms of employment law, basically is to guarantee and provide decent employment opportunities for Indonesian citizens in various fields and levels. ${ }^{x i}$ The regulation on the use of foreign workers does not only provide opportunities for foreigners to work in Indonesia, but also limit the use of foreign workers in Indonesia. The presence of foreign workers in Indonesia must benefit the national interest. Article 42 of Law Number 13 Year 2003 concerning 
Manpower regulates the requirements for employers to employ foreign workers. These provisions state as follows:

(1) Every employer employing foreign workers must have written permission from the Minister or appointed official.

(2) Individual employers must not employ foreign workers.

(3) Obligations to have a permit as referred to in paragraph (1), do not apply to representatives of foreign countries that use foreign workers as diplomatic and consular employees.

(4) Foreign workers can be employed in Indonesia only in employment relationships for certain positions and for certain periods of time.

(5) Provisions regarding certain positions and certain times as referred to in paragraph (4) are determined by Ministerial Decree.

(6) Foreign workers as referred to in paragraph (4) whose term of service expires and cannot be extended can be replaced by other foreign workers.

Article 2 Presidential Regulation of the Republic of Indonesia Number 20 of 2018 concerning the Use of Foreign Workers stipulates that the use of foreign workers is carried out by the employer of foreign workers in employment relations for certain positions and times. The use of foreign workers is carried out with due regard to domestic labor market conditions. Employers of foreign workers include:

1. government agencies, representatives of foreign countries, international bodies, and international organizations;

2. a foreign trade representative office, a foreign company representative office, and a foreign news agency that carries out activities in Indonesia;

3. foreign private companies operating in Indonesia;

4. legal entity established under Indonesian law in the form of a Limited Liability Company or Foundation, or a foreign business entity registered with the competent authority;

5. social, religious, educational and cultural institutions;

6. impresariat service business; and

7. business entity as long as it is not prohibited by Law.

Employers using foreign workers must have a plan for the use of foreign workers approved by the Minister or appointed official. The plan to use foreign workers must at least contain information:

a. reasons for using foreign workers;

b. position and / or position of foreign workers in the organizational structure of the company concerned;

c. the period of use of foreign workers; and d. the appointment of Indonesian workers as accompanying foreign workers employed.

Employers of foreign workers must obey the provisions regarding the position and applicable competency standards. Employers of foreign workers are required:

a. appointing Indonesian citizens as accompanying foreign workers employed for technology and expertise transfer from foreign workers; and

b. conducting work education and training for Indonesian workers in accordance with the qualifications of positions occupied by foreign workers.

As workers, foreign workers are also entitled to get protection. Protection of labor as mentioned in the preamble of Law Number 13 Year 2003 concerning Manpower is intended to guarantee the basic rights of workers / laborers and guarantee equal opportunity and treatment without discrimination on any basis to realize the welfare of workers / laborers and their families while still paying attention to developments progress of the business world. This protection covers the welfare, safety, and health of both mental and physical labor.

Better labor protection is aimed at improving wages, working conditions, and employment relationships, occupational safety and health and other social security. ${ }^{\text {ii }}$ This workforce protection objective is in line with the mandate of Article 23 of The Universal Declaration of Human Rights as stated:

Article 23

(1) Everyone has the right to work, to free choice of employment, to just and favourable conditions of work and to protection against unemployment.

(2) Everyone, without any discrimination, has the right to equal pay for equal work.

(3) Everyone who works has the right to just and favourable remuneration ensuring for himself and his family an existence worthy of human dignity, and supplemented, if necessary, by other means of social protection.

(4) Everyone has the right to form and to join trade unions for the protection of his interests.

Labor protection as written by Zaenal Asikin covers aspects, namely:

a. Legal protection, i.e. if it can be implemented legislation in the field of labor that requires or forces the employer to act in accordance with these laws and actually carried out by all parties concerned.

b. Economic protection, which is protection relating to efforts to provide workers with an income that is sufficient to meet their daily needs for themselves and their families.

c. Social protection, which is protection relating to social enterprises whose purpose is to enable workers to enjoy and develop their lives as humans and as members of society. 
d. Technical protection, which is protection relating to efforts to protect workers from the dangers of accidents caused or related to occupational safety and health. ${ }^{\text {xii }}$

According to Article 47 of Law Number 13 Year 2003 concerning Manpower, the employer is obliged to pay compensation for each foreign labor employed by him. The obligation to pay compensation as referred to in paragraph (1) does not apply to government agencies, representatives of foreign countries, international bodies, social institutions, religious institutions, and certain positions in educational institutions. Employers who employ foreign workers are required to repatriate foreign workers to their country of origin after the employment relationship has ended.

In carrying out work relations, dispute conditions may occur. Disputes in employment relations are termed industrial disputes. Industrial relations disputes are differences of opinion which result in disagreement between employers or employers' associations with workers / laborers or trade / labor unions due to disputes regarding rights, disputes of interest, and disputes about termination of employment and disputes between trade unions / labor unions in only one company.

Disputes arise because of disagreements about what has been agreed by both parties. A harmonious work relationship will minimize the existence of conflict in the workplace. Thus, between employers and workers / laborers there will be no mutual hostility, there is mutual respect, mutual understanding of what are their respective rights and obligations, and help each other, in which these conditions increase the added value of a company where it works in the face of competition. ${ }^{\text {xiv }}$ Law of the Republic of Indonesia Number 2 of 2004 concerning Settlement of Industrial Relations Disputes develops and institutionalizes 4 (four) types of industrial relations disputes, namely:

1. Disputes over rights;

2. Disputes of interest;

3. Work termination disputes;

4. Disputes between trade unions / labor unions in one company.

Alternative dispute resolution is an effort to settle disputes outside the court. Attempts to find alternative forms of dispute resolution occur when Warren Burger (former Chief Justice) was invited to a conference called the Roscoe Pound Conference on the Causes of Popular Dissatisfaction with the Administration of Justice (Pound Conference) in Saint Paul, Minnesota. Academics, legal observers, and lawyers concerned with dispute issues gathered together at the conference. Several papers submitted at the conference were finally compiled into a basic understanding of dispute resolution at the time ${ }^{\mathrm{xv}}$ namely the resolution of disputes outside the court (non-litigation) or termed as alternative dispute resolution. Christopher Kuner, did not provide a definition of Alternative Dispute Resolution, he only stated: The term 'alternative dispute resolution' can include a wide variety of dispute resolution mechanisms outside the court system, including arbitration, mediation, consumer compalint systems, etc., so that it can be difficult to define exactly what is meant by the term. ${ }^{\mathrm{xvi}}$ Dispute resolution outside the court can be done in various ways including arbitration, mediation, negotiation and so on.

According to the provisions in Article 136 of Law Number 13 Year 2003 concerning Labor, it states:

(1) Settlement of industrial relations disputes shall be carried out by employers and workers / laborers or trade unions / labor unions by deliberation to reach consensus.

(2) In the event that deliberation to reach consensus as referred to in paragraph (1) is not reached, the employer and worker / laborer or trade union / laborer will settle industrial relations disputes through the procedures for resolving industrial relations disputes regulated by law.

Article 3 of the Law of Republic of Indonesia No. 2 Year 2004 concerning Settlement of Industrial Relations Disputes states

(1) Industrial relations disputes must be resolved in advance through deliberate bipartite negotiations to reach consensus.

(2) Settlement of disputes through bipartite as referred to in paragraph (1), must be settled no later than 30 (thirty) working days from the date of the start of negotiations.

(3) If within a period of 30 (thirty) days as referred to in paragraph (2) one of the parties refuses to negotiate or the negotiations have been conducted but the agreement is not reached, the bipartite negotiations shall be deemed a failure.

In the event that bipartite negotiations fail, one or both parties register their dispute with the agency responsible for local manpower by attaching evidence that remedial efforts through bipartite negotiations have been made. If the evidence is not attached, the agency responsible for manpower returns the file to be completed no later than 7 (seven) working days from the date of receipt of the file return. Accepting records from one or the parties, the agency responsible for local employment must offer the parties to agree on choosing a settlement through conciliation or through arbitration.

In the event that the parties do not determine a settlement option through conciliation or arbitration within 7 (seven) working days, the agency responsible for labor affairs delegates the dispute resolution to the mediator. Settlement through conciliation is carried out to settle conflicts of interest, disputes over termination of employment, or disputes between trade unions / labor unions. Settlement through arbitration is carried out to settle conflicts of interest or disputes between trade unions / labor unions.

Settlement of disputes through mediation is carried out by mediators who are in each office of the agency responsible for the Regency / City manpower field. In the event that an industrial relations dispute resolution agreement is reached through mediation, a Joint Agreement is signed by the parties and witnessed by the mediator and registered at the 
Industrial Relations Court at the District Court in the jurisdiction of the parties entering into a Joint Agreement to obtain the deed of registration. In the event that an industrial relations dispute settlement agreement is not reached through mediation, then:

a. the mediator issues written recommendations;

b. the written recommendation as referred to in letter a within 10 (ten) working days after the first mediation session must be submitted to the parties;

c. the parties must have given a written response to the mediator whose contents approve or reject the written suggestion within no later than 10 (ten) working days after receiving the written recommendation;

d. a party who does not give its opinion as referred to in letter $\mathrm{c}$ shall be deemed to reject written recommendations;

e. in the event that the parties agree to the written recommendation as referred to in letter a, within no later than 3 (three) working days after the written recommendation is approved, the mediator must have finished helping the parties make a Joint Agreement to be then registered at the Industrial Relations Court at the District Court in the jurisdiction the parties enter into a Joint Agreement to obtain a proof of registration deed.

Registration of Joint Agreement is at the Industrial Relations Court at the District Court. The Joint Agreement that has been registered is given a proof of registration deed and is an inseparable part of the Joint Agreement. If a Joint Agreement is not implemented by one of the parties, the injured party may submit an application for execution to the Industrial Relations Court at the District Court in the Joint Agreement area to be registered to obtain an execution determination. In the case of an applicant for execution domiciled outside the jurisdiction of the Industrial Relations Court at the District Court where the Joint Agreement is registered, the execution applicant may submit an application for execution through the Industrial Relations Court at the District Court in the area of the applicant's execution to be forwarded to the Industrial Relations Court at the competent District Court carrying out the execution.

Settlement of industrial relations disputes through arbitration includes disputes over interests and disputes between trade unions / labor unions in only one company. Arbitrators who are authorized to settle industrial relations disputes must be arbitrators determined by the Minister. The settlement of industrial relations disputes through arbitration includes disputes of interests and disputes between trade unions / labor unions in only one company.

In the event that a settlement through conciliation or mediation does not reach an agreement, one of the parties may file a lawsuit with the Industrial Relations Court. The Industrial Relations Court is a special court within the general court environment. The Industrial Relations Court has the duty and authority to examine and decide:

a. at the first level concerning rights disputes; b. at the first and last level regarding disputes of interest;

c. at the first level concerning disputes over termination of employment;

d. at the first and last level concerning disputes between trade unions / labor unions in one company.

The industrial relations dispute court can re-examine the dispute at a higher court, because the issue of termination of employment is a sensitive and complex issue and is directly related to the continuity of one's income. ${ }^{\text {xvii }}$

\subsection{The law used in dispute resolution through alternative dispute resolution}

Legally, the parties do not have the ability to make their own laws. There is no authority to create laws for the contracting parties. However, they are only given the freedom to choose which law is desired to apply to the contract made. They are not given the authority to autonomously determine their own laws that must apply to them. New approaches to choice of law, starting with the governmental-interest analysis developed by the American legal scholar Brainerd Currie, began to emerge in the 1950s. Currie's approach sought to determine whether a "true" or "false" conflict exists between the law of the forum state and that of the other involved state. A false conflict exists if the laws of both states do not differ; if, although significantly different, both laws are designed to effect the same policy; or if one law is construed to be applicable to cases such as the one before the court. If by these guidelines the other state is determined not to have an interest, a false conflict exists, thus making the local law of the forum of the applicable choice of law. ${ }^{\text {viii }}$

This choice of law is part of the freedom of contract, namely the parties are free to determine the contents of the contract, including the choice of law. This principle of freedom of contract in Indonesia is adhered to in article 1338 of the Civil Code, namely:

"All agreements made in accordance with the law apply as the law for those who make them. The agreement cannot be withdrawn other than by agreement of the two parties, or for reasons determined by law "

Choice of law in agreement law is the freedom granted to the parties to choose their own law to be used in the agreement. There are several forms of the choice of law in Indonesia, as follows:

1. Strictly stated by the parties in the contract

2. Secretly or impliedly

3. The agreement of the parties to submit legal choices to the court

4. Determination of the parties not to choose legal options. ${ }^{\text {xix }}$

The exercise of choice of law in a conflict of law gives the parties the right to determine the applicable law for them. 
The judges from all countries in the world respect the choice of law of the parties. However, there are restrictions through the application of the principle of public order, for example based on national laws of the country concerned. If the chosen law does not have a substantive relationship with the transaction and does not have sufficient reasons for the legal choice of the parties, the judge will determine which law applied. The state law of the judge that adjudicates can be the basis of the settlement if the law chosen by the parties cannot be applied in the dispute that occurs.

Choice of law can be made since the preparation of a work agreement. The work agreement is an agreement between the worker / laborer and the employer which contains the terms of employment, rights, and obligations of the parties. The work agreements are made in written or spoken form. The work agreements required in writing are implemented in accordance with applicable laws and regulations. The work agreement is made based on the agreement of both parties; the ability to carry out legal actions; the existence of the promised work; and the promised work does not conflict with public order, decency, and the applicable laws and regulations. All matters and / or costs required for the implementation of the work agreement are carried out by and are the responsibility of the employer

An examination of the existence of legal options in the resolution of industrial disputes in Indonesia occurred in the case between Bui Khoi Hung Gilbert and PT Tirta Investama (Aqua) and Danone Asia PTE Ltd. According to the panel of leaders Lilik Mulyadi, the court was not authorized to hear the case of both parties. Gilbert is a French citizen who works at Aqua. The work agreement was signed by Gilbert in Singapore with Danone PTE Ltd management in Singapore. In a work agreement dated May

\section{CONCLUSION}

Labor dispute resolution between companies in Indonesia and foreign workers can be resolved through alternative dispute resolution through deliberation, mediation, conciliation and arbitration. If the method cannot resolve industrial relations disputes between the parties, they can submit the case to the industrial relations court. Dispute resolution through alternative dispute resolution uses the choice of law that is the law chosen by the parties. The choice of law is contained in a work agreement between the company and foreign workers.

\section{ACKNOWLEDGMENT}

\section{Universitas Mahasaraswati Denpasar and Institut Hindu Dharma Denpasar as our affiliation.}

10, 2004, both parties agreed to choose Singapore law in solving problems. Despite signing a contract in Singapore, Gilbert was employed as Security Director at Aqua (Tirta Investama) Indonesia. Since 30 June 2006, Tirta Investama has no longer extended Gilbert's contract. He considered the action baseless. Because, Aqua acted as a sponsor for himself in getting a Foreign Workers Permit (IMTA). Aqua also recognized Gilbert as an employee and paid him as printed on the Limited Stay Permit Card (Kitas) and reported on the presence of foreign workers to the East Jakarta Manpower and Transmigration Office. ${ }^{\mathrm{xx}}$

Although Indonesian labor law applied at that time, the panel of judges considered that the employment agreement between Gilber and Danone-Aqua was a lex specialis for both parties. Each industrial relations dispute experienced by the plaintiff with Aqua Indonesia, in this case Termination of Employment, must be settled under Singapore law in the Singapore court jurisdiction. The Assembly recognized the choice of law Gilbert and Danone had promised.

The choice of law as contained in the employment agreement between foreign workers and companies in Indonesia will be the basis for resolving industrial relations disputes. This will affect the choice of forum from the parties to solve the problem. National court competencies may shift or be shifted by the competency of the forum designated as a dispute resolution agency by the parties. The intended forum can be an institution (institutionalized) or in the form of an ad hoc forum. Usually, this forum is present because it was chosen by the parties, so that the dispute is resolved through an agreed forum or it can also be attended because it is determined by the applicable law in a country.

\section{REFERENCES}

[1]. Indonesia Investment, Foreign Workers in Indonesia: a Threat or Tactic to Gain Votes?, https://www.indonesiainvestments.com/id/news/newscolumns/foreign-workers-in-indonesia-a-threator-tactic-to-gain-votes/item8790?

[2]. Syahmardan, Tenaga Kerja Asing di Indonesia: Kebijakan dan Implementasi, http://ditjenpp.kemenkumham.go.id/hukumbisnis/1427-tenaga-kerja-asing-di-indonesiakebijakan-dan-implementasi.html

[3]. Agusmidah, Dinamika Hukum Ketenagakerjaan Indonesia, Medan: USU Press, 2011, p. 11.

[4]. Syprianus Aristeus, Penelitian Hukum tentang Peranan Hukum Investasi di Indonesia dalam Era Globalisasi, Jakarta: Badan Pembinaan Hukum Nasional Departemen Hukum dan HAM RI, 2007, p. 80.

[5]. CNN Indonesia, Kemenaker Nyatakan Jumlah Tenaga Kerja Asing hanya 90 Ribu, 
https://www.cnnindonesia.com/ekonomi/201901 11230814-92-360311/kemenaker-nyatakanjumlah-tenaga-kerja-asing-hanya-90-ribu

[6]. Hasanudin Abdurakhman, Tenaga Kerja Asing, Antara Perlu dan Tidak https://news.detik.com/kolom/d3911332/tenaga-kerja-asing-antara-perlu-dantidak

[7]. Saiful Anwar, Sendi-sendi Hubungan Pekerja dengan Pengusaha, Medan: Kelompok Studi Hukum dan Masyarakat Fakultas Hukum Universitas Sumatera Utara, 2007,p. 13.

[8]. Ahmadi Miru, Hukum Kontrak dan Perancangan Kontrak, Jakarta: PT. Rajagrafindo Persada, 2008, p. 35.

[9]. Budiono, Abdul Rachmat, Hukum Perburuhan di Indonesia, Jakarta: PT. Rajagrafindo Persada, 1995, p. 115.

[10]. Adrian Sutedi, Hukum Perburuhan, Jakarta: Sinar Grafika, 2009, p. 23.

[11]. Agusmidah, Hukum Ketenagakerjaan Indonesia (Dinamika dan Kajian Teori), Jakarta: Ghalia Indonesia, 2010, p. 111.

[12]. Carlton Clymer Rodee et.al, Pengantar Ilmu Politik, Jakarta: RajaGrafindo Persada, 2009, p. 206.

[13]. Zaenal Asikin et.al., Dasar-Dasar Hukum Perburuhan, Jakarta: Rajawali Pers, 2010, p. 76.

[14]. Adrian Sutedi, Hukum Perburuhan, Jakarta: Sinar Grafika, 2009, p. 24.

[15]. Jacqueline $M$ Nolan dan Haley, Alternative Dispute Resolution in a Nutshell, USA: West Publishing Co, St. Paul, Minnesota, 1992, p. 4.

[16]. Kuner, Christopher, Legal Obstacles to ADR in European Business-to-Consumer Electronic Commerce (article), 2000, p. 1

[17]. Agusmidah, Hukum Ketenagakerjaan Indonesia (Dinamika dan Kajian Teori), Jakarta: Ghalia Indonesia, 2010, p. 185.

[18]. Ensiclopedia Britannica, Contemporary developments, https://www.britannica.com/topic/conflict-oflaws/Choice-of-law

[19]. Sudargo Gautama, Hukum Perdata Internasional Indonesia, Bandung: Alumni, 1998, p. 148

[20]. Hukum Online, Pilihan Hukum Menjadi Lex Specialis dalam Perjanjian Kerja, https://www.hukumonline.com/berita/baca/hol16 556/pilihan-hukum-menjadi-ilex-specialisidalam-perjanjian-kerja-/ 